\title{
Pemberdayaan Masyarakat Melalui Pemanfaatan Lidi Kelapa di Desa Grogolpenatus Kecamatan Petanahan Kabupaten Kebumen
}

\author{
Warto ${ }^{1^{*}}$, Agus Sriyanto ${ }^{1}$ \\ ${ }^{1}$ Fakultas Dakwah IAIN Purwokerto
}

Article Information

Submited April 29, 2021

Revised Mei 19, 2021

Accepted Juni 27, 2021

Published Juli 31, 2021

\begin{abstract}
Villagers living in agrarian areas with tropical seasons have a lot of potential for abundant natural resources. If it can take advantage of this potential, it becomes an additional source of income for the villagers. Some of the villagers of Grogolpenatus still live in poverty line. In fact, the village has the potential of natural resources in the form of lidi waste that can be utilized by weaving, so as to provide additional income and further increase the economic level of the citizens. With direct involvement, the community feels that it has a program and is expected to run sustainably. Empowerment methods with a bottom-up system invite the community to be directly involved in the process of identification, idea discovery, implementation, to the evaluation of community empowerment programs. While the method of implementation by carrying out woven training lidi with participants pkk mothers and young women. The process of identifying natural resources in grogolpenatus village was found a lot of lidi waste, but not utilized. Next, came the idea to make various crafts from woven lidi. Lidi webbing training brings presenters who are practitioners of woven lidi. The participants of the woven training lidi are pkk mothers grogolpenatus village. After attending the lidi webbing training, pkk mothers and young women became understanding and skilled in weaving lidi in various interesting forms. The results of woven lidi are then marketed at petanahan beach tourist sites and Petanahan market.
\end{abstract}

Keywords: Community empowerment; woven lidi; natural resources; villagers

Masyarakat desa yang hidup di daerah agraris dengan musim tropis memiliki banyak potensi sumber daya alam yang melimpah. Jika bisa memanfaatkan potensi tersebut maka bisa menjadi sumber tambahan penghasilan bagi masyarakat desa. Sebagian warga desa Grogolpenatus masih ada yang hidup dalam garis kemiskinan. Padahal desa tersebut memiliki potensi sumber daya alam berupa limbah lidi yang bisa dimanfaatkan dengan menganyam sehingga bisa memberikan penghasilan tambahan dan selanjutnya bisa meningkatkan tarap ekonomi warga. Dengan pelibatan secara langsung maka masyarakat merasa memiliki program dan diharapkan bisa berjalan secara berkelanjutan. Metode pemberdayaan dengan system bottom-up mengajak masyarakat untuk terlibat langsung dalam proses identifikasi, penemuan ide, pelaksanaan hingga evaluasi program pemberdayaan masyarakat. Sedangkan metode pelaksanaan dengan melaksanakan pelatihan anyaman lidi dengan peserta ibu-ibu PKK dan remaja putri. Proses identifikasi sumberdaya alam yang ada di desa Grogolpenatus ditemukan limbah lidi yang banyak, namun tidak dimanfaatkan. Selanjutnya muncul ide untuk membuat berbagai kerajinan dari anyaman lidi. Pelatihan anyaman lidi mendatangkan pemateri yang merupakan praktisi anyaman lidi. Peserta pelatihan anyaman lidi yaitu ibu-ibu PKK desa Grogolpenatus. Setelah mengikuti pelatihan anyaman lidi, para Ibu-ibu PKK dan remaja putri menjadi paham dan terampil cara menganyam lidi dengan berbagai bentuk yang menarik. Hasil anyaman lidi kemudian dipasarkan di lokasi wisata pantai Petanahan dan pasar Petanahan.

Kata Kunci: Pemberdayaan Masyarakat; Anyaman Lidi; Sumber Daya Alam; Masyarakat Desa

*Korespondensi Penulis: Warto, Email: warto@iainpurwokerto.ac.id, Alamat: Jl. A. Yani No. 40-A Purwokerto, Jawa Tengah, 53126

Copyright (C) 2021 Warto, Agus Sriyanto 


\section{Pendahuluan}

Paradigma lama dalam program pemberdayaan masyarakat yaitu penerima masyarakat berposisi sebagai obyek. Penerima manfaat diposisikan sebagai sekumpulan orang pasif, yang menerima bantuan pemberdayaan dari pihak luar, dalam hal ini program pemberdayaan. Sedangkan paradigma baru dalam pemberdayaan masyarakat menempatkan penerima manfaat sebagai subyek (Utama, 2020). Penerima manfaat diposisikan secara aktif memiliki potensi yang jika digali secara optimal bisa memberdayakan diri mereka sendiri dengan kekuatan yang mereka miliki. Paradigma kedua ini lebih manusiawi karena menuntun penerima manfaat untuk bisa mandiri, selain itu juga merasa memiliki program yang mereka rancang Bersama dengan fasilitator.

Pemberdayaan masyarakat menjadi salah satu isu yang banyak dikaji oleh para akademisi. Dengan kondisi masyarakat yang sangat beragam, pemberdayaan masyarakat di Indonesia juga memeberikan tantangan yang berbeda di setiap wilayah. Misalnya, pemberdayaan masyarakat kota (Kurniati, 2013) berbeda dengan pendekatan pemberdayaan masyarakat desa (Putra, 2013). Pemberdayaan msayarakat di Jawa berbeda dengan pemberdayaan masyarakat di luar Jawa.

Perbedaan tersebut karena dipengaruhi oleh beberapa faktor diantaranya: a) tingkat pendidikan, b) mata pencaharian, c) lingkungan sekitar, d) sumber daya alam. Tingkat pendidikan masyarakat kota relatif lebih tinggi dibanding dengan masyarakat pedesaan. Masihadabeberapadaerahpedesaan yang tidak mementingkan pendidikan dalam keluarganya. Hal ini mengakibatkan potensi intelektual masyarakat desa tidak bisa tergali secara optimal. Kendati demikian, sasaran pengembangan masyarakat adalah masyarakat berada di ambang kemiskinan dan di bawah garis kemiskinan, maka faktor pendidikan ini relatif sama antara masyarakat desa dan masyarakat kota.

Mata pencaharian masyarakat kota sangat berbeda dengan masyarakat desa. Masyarakat kota yang berada di ambang kemiskinan dan di bawah garis kemiskinan kebanyakan memiliki mata pencaharian sebagai pemulung, pengemis, penjual makanan keliling, penjual sayuran keliling, pembantu rumah tangga, buruh serabutan, dan lain-lain. Sedangkan profesi masyarakat desa kebanyakan adalah sebagai petani, buruh tani, peternak, dan sejenisnya.

Perbedaan yang lain terletak pada karakteristik masyarakat. Pada masyarakat desa, kental dengan gotong-royong. Karakteristik lingkungan di pedesaan cenderung rukun antar tetangga saling kenal, bahkan tetangga jauh. Sedangkan masyarakat kota lebih individualistik, antar tetangga bisa jadi tidak saling kenal. Hal ini cukup dipahami karena pada masyarakat kota kebanyakan adalah pendatang dari desa yang merantau dan mengadu nasib di perkotaan.

Perbedaan yang keempat yaitu sumber daya alam. Sumber daya alam yang ada di desa jauh lebih variatif dibanding dengan sumber daya alam yang ada di perkotaan. Keterbatasan sumber daya alam yang ada di perkotaan disebabkan karena kebutuhan gedung dan perubahan yang sangat tinggi. Sedangkan di desa masih tersedia sumber daya alam yang melimpah karena masih banyak lahan produktif maupun lahan tidak produktif. Berbagai perbedaan tersebut yang kemudian menjadikan perbedaan metode dan pendekatan dalam memberikan pelayanan 
pengembangan masyarakat.

Berbagai pendekatan pemberdayaan masyarakat diusulkan oleh para peneliti, diantaranya pendekatan berdasar cakupan penerima manfaatyaitu:a) pendekatan mikro, b) pendekatan mezzo, dan c) pendekatan makro (Haris, 2014; Silmi, 2017). Pendekatan mikro mengacu pada pemberdayaan masyarakat pada skala mikro atau individu. Kelebihan dari pendekatan ini yaitu hasil bisa terukur dengan jelas dan bisa fokus. Sedangkan kekurangannya yaitu dampak yang dihasilkan berskala kecil. Fasilitator pemberdayaan masyarakat pada skala mikro bisa dilaksanakan oleh perseorangan atau secara individu.

Pendekatan mezzo memiliki cakupan penerima manfaat yang lebih luas. Misalnya, dalam wilayah RT/RW atau pada kelompok yang memiliki karakteristik homogen. Pada masyarakat desa misalnya pemberdayaan pada masyarakat petani, peternak, ibu rumah tangga, pemuda pengangguran dan sejenisnya. Sedangkan pada masyarakat kota misalnya pada kelompok pemulung, pengemis, dan sejenisnya (Setiawan, 2012; Hatu, 2010). Pada skala ini penerima manfaat bisa lebih banyak, namun membutuhkan effort yang juga tidak sedikit. Pada skala ini mulai ada dinamika kelompok, misalnya terkait persinggungan kepentingan individu dan ego yang muncul pada anggota yang memiliki pengaruh lebih tinggi dibanding yang lain. fasilitator harus bisa mengelola dinamika kelompok yang terjadi, jangan sampai malah menjadikan kontra-produktif terhadap program pemberdayaan yang dijalankan. Program pemberdayaan pada skala mezzo ini bisa dilaksanakan oleh fasilitator secara individua tau kelompok kecil.
Pendekatan makro memiliki cakupan yang lebih luas yaitu pada tingkat dusun, desa, keluruhan, atau pada tingkat kelompok masyarakat yang lebih heterogen. Pada skala makro memberikan tantangan yang lebih besar karena penerima manfaat yang memiliki karakteristik lebih heterogen. Program pemberdayaan pada skala makro ini biasanya dilaksanakan oleh kelompok yang lebih besar. Pelaksana program ini umumnya adalah Perguruan Tinggi, Lembaga Swadaya Masyarakat (LSM) atau Non-Govermental Organization (NGO) pada skala nasional ataupun internasional.

Jika dibandingkan dengan wilayah perkotaan, salah satu keunggulan desa yaitu potensi sumber daya alam yang melimpah (Soleh, 2017; Suryawan, 2016; Wuysang, 2014). Sumber daya alam jika dimanfaatkan dengan baik maka bisa mendatangkan keuntungan ekonomi bagi masyarakat desa. Keadaan tersebut bisa menjadi peluang dalam meningkatkan taraf ekonomi masyarakat desa.

Program kegiatan dan penelitian terkait pemberdayaan masyarakat desa yang telah dilakukan oleh civitas akademika IAIN Purwokerto diantaranya oleh (Deti, 2017, Budiningsih, 2019; Laksono, 2016; Martiarini, 2017; Indarti, 2019). Dari berbagai publikasi terkait pengabdian dan penelitian tersebut menjadi khasanah dan keterlibatan IAIN Purwokerto dalam ikut serta berperan aktif memberikan kemanfaatan bagi masyarakat sekitar. Pengabdian ini juga dalam rangka memberikan kemanfaatan yang lebih luas kepada masyarakat desa Grogolpenatus dalam mengenali dan memanfaatkan potensi desa yang mereka miliki.

Penduduk desa Grogolpenatus, Kecamatan Petanahan, Kabupaten Kebumen, ke- 
banyakan berprofesi sebagai petani. Oleh karena itu, masih cukup banyak waktu yang bisa dimanfaatkan untuk aktivitas produktif lain, karena kesibukan petani hanya pada saat musim tanam dan musim panen saja. Hal ini menjadi peluang atau potensi masyarakat untuk bisa memanfaatkan waktu luang dengan aktifitas produktif yang berbasis pada pemanfaatan potensi sumber daya alam yang tersedia disekitarnya.

Desa Grogolpenatus memiliki sumber daya alam pohon kelapa yang banyak, hanya saja pemanfaatanya baru sebatas pada buahnya. Sedangkan potensi lain dari pohon kelapa belum termanfaatkan secara optimal. Potensi tersebut misalnya batang daun kelapa, atau biasa disebut lidi. Lidi yang selama ini belum dimanfaatkan secara lebih produktif, bisa menjadi bahan untuk membuat kerajinan yang lebih bernilai ekonomis.

Manusia dianugerahi akal pikiran untuk bisa memikirkan semua hal yang ada di sekitarnya. Ayat-ayat Allah SWT tidak hanya dalam bentuk qauliyah, namun lebih banyak qauniyah. Dengan membaca, memikirkan alam sekitar serta memanfaatkan dengan sebaikbaiknya, sebenarnya kita sedang membaca ayat qauniyah Allah SWT. Sebagaimana tercantum dalam firman Allah SWT di AlQur'an Surat Yunus ayat 101:

Qulinzurụ māżā fis-samāwāti wal-arḍ, wa mā tugnil-āyātu wan-nużuru 'ang qaumil lā yu'minụn

Artinya: "Katakanlah: "Perhatikanlah apa yaag ada di langit dan di bumi. Tidaklah bermanfaat tanda kekuasaan Allah dan rasul-rasul yang memberi peringatan bagi orang-orang yang tidak beriman".

Maksud ayat ini berdasar tafsir $\mathrm{Al}$ Misbah (Shihab, 2002) adalah mendorong umat manusia untuk mengembangkan ilmu pengetahuan melalui kontemplasi, eksperimentasi, dan pengamatan. Ayat ini juga mengajak untuk menggali pengetahuan yang berhubungan dengan alam raya dan isinya. Sebab, alam raya yang diciptakan untuk kepentingan manusia ini, hanya dapat dieksplorasi melalui pengamatan inderawi.

Gambaran implementasi ayat tersebut adalah penelitian yang dilakukan oleh para akademisi dan profesional. Namun sebenarnya pengamatan pada lingkungan sekitar, yang dilakukan oleh siapapun termasuk masyarakat desa juga memiliki nilai yang sama di hadapan Allah SWT. Apalagi dalam rangka untuk membuka peluang pemanfaatan secara ekonomis menjadi urgen dan relevan berdasar Surat Yunus ayat 101 dan tafsir Al-Misbah.

Pemanfaatan lidi sebagai kerajinan telah banyak dilakukan di berbagai tempat, misalnya (Azzahra \& Hasan, 2018; F., Maricar, \& Asnudin, 2018; Herlina, Yuliani, Kader, \& Syarifudin, 2018; Irianti, Syahza, Asmit, Bakce, \& Tampubulon, 2018; Magga \& Jamaluddin, 2019; Rahman \& Budiywono, 2018). Bahkan lidi juga dimanfaatkan untuk pembuatan komposit hibrida sebagai bahan bangunan alternatif (Siregar, 2007). Menyadari besarnya potensi lidi yang ada di Grogolpenatus, maka dirasa perlu untuk memberikan pengetahuan dan keterampilan dalam bentuk pelatihan pemanfaatan lidi menjadi produk yang bernilai ekonomi.

Sudah menjadi pengetahuan umum, pohon kelapa memiliki manfaat pada semua bagiannya. Mulai dari ujung atas hingga akarnya semua bisa menjadi komoditas ekonomi. Fenomena yang terjadi di desa Grogolpenatus, blukang (batang daun kelapa) dimanfaatkan sebagai kayu bakar. Sedangkan klari (daun dan lidi) dimanfaatkan sebagai pemantik api di tungku saat akan 
memasak. Namun demikian, masih banyak juga klari tidak terpakai dan dibiarkan teronggok di pekarangan. Fenomena ini kemudian memunculkan ide warga untuk memanfaatkannya agar bernilai ekonomis. Setelah melakukan searching di internet dan ada juga beberapa warga yang mengetahui pemanfaatan lidi sebagai anyaman gerabah, maka muncullah ide untuk membuat anyaman lidi dari bahan yang banyak tersedia di desa Grogolpenatus.

Dengan pelaksanaan kegiatan pelatihan menganyam lidi menjadi gerabah, ada beberapa masalah yang terselesaikan yaitu:

1. Menambah aktivitas positif bagi warga yang memiliki banyak stok daun kelapa untuk bisa dimanfaatkan dan mendatangkan nilai ekonomi. Hasil anyaman bisa dijual di obyek wisata Pantai Petanahan yang tidak jauh dari rumah warga.

2. Mengurangi sampah daun kelapa yang ada di pekarangan.

\section{Metode Pelaksanaan}

Metode pelaksanaan pemberdayaan masyarakat dilakukan dengan menempatkan masyarakat sebagai aktor utama (Zuliyah, 2010). Metode ini sesuai dengan pendekatan pemberdayaan yang masyarakat yang menempatkan masyarakat sebagai subyek. Strategi yang digunakan dalam program ini yaitu modifikasi pola dan perilaku dengan pendidikan dan aksi lainnya (Nasdian, 2014). Pola berpikir orang desa yang cenderung menerima apa adanya menjadikan masyarakat hidup sederhana tanpa keinginan aneh yang bermacam-macam. Pola pikir semacam ini yang kemudian menjadikan mereka tidak sensitif terhadap potensi sumber daya alam yang ada di sekitar mereka. Dengan mengajak mereka belajar berpikir tentang potensi tersebut, maka secara tidak langsung dan lambat laun mengubah pola berpikir sederhana menjadi lebih kritis terhadap lingkungan sekitarnya. Dengan munculnya pola berpikir yang baru, maka bisa secara langsung mempengaruhi perilaku mereka yang lebih kritis dan bergerak memanfaatkan potensi yang selama ini tidak terpikirkan oleh mereka. Sampai di sini masyarakat kemudian timbul keinginan untuk belajar bagaimana memanfaatkan potensi lidi. Dengan demikian, muncullah program pelatihan anyaman lidi. Pelatihan anyaman ini adalah sebagai wujud pendidikan dan aksi lainnya dalam rangka untuk belajar bagaimana memanfaatkan lidi agar bisa memiliki nilai ekonomi yang pada akhirnya nanti bisa meningkatkan taraf hidup masyarakat.

Sasaran kegiatan ini adalah ibu-ibu PKK dan remaja putri desa Grogolpenatus. Sedangkan karang taruna berperan sebagai koordinator dan pelaksana kegiatan pelatihan yang bekerjasama dengan tim KKN dari IAIN Purwokerto. Kegiatan ini dilaksanakan selama satu hari penuh dari jam 08.00-16.00 WIB yang bertempat di Aula Balai Desa Grogolpenatus, Petanahan, Kebumen, Jawa Tengah. Pengabdian ini dilaksanakan melalui tiga tahap:

Pertama, tahap pembentukan perilaku. Tahap ini dilakukan sebelum pelatihan diberikan. Intinya membangun kesadaran masyarakat untuk menggali dan lebih mengenali potensi desa yang bisa menjadi salah satu media tambahan penghasilan ekonomi keluarga.

Kedua, tahap pelatihan keterampilan pembuatan piring berbahan baku lidi kelapa. Pelatihan ini mendatangkan narasumber yang 
memiliki pengalaman dalam memberikan pelatihan anyaman lidi. Masyarakat desa Grogolpenatus diminta membawa bahan baku berupa lidi kelapa yang siap untuk dianyam pada saat pelatihan berlangsung. Pada tahap awal pelatihan, pemateri memberikan penjelasan secara "teori" mengenai lidi dan anyaman lidi. Setelah itu melakukan demonstrasi menganyam lidi sambil memberikan penjelasan teknik dan cara menganyam yang rapi dan bagus, sebagaimana terlihat pada gambar 1 . Setelah sesi demo selesai, peserta diajak untuk langsung praktik menganyam lidi yang sudah dibawanya dari rumah, sebagaimana terlihat pada gambar 2. Pemateri sambil mengamati dan memberikan penjelasan sambal mempraktikkan serta mendekati peserta yang kelihatan masih bingung memulai proses anyaman. Latihan menganyam dimulai dari yang paling mudah, kemudian beranjak ke tahap yang lebih detail dan butuh ketelitian. Hingga akhir acara pelatihan, sebagian besar peserta cukup paham membuat anyaman lidi dalam berbagai bentuk seperti piring dan mangkok.

Ketiga, tahap pendampingan pasca pelatihan. Tahap ini untuk memastikan pelatihan yang dilaksanakan bisa langsung diterapkan dan dilaksanakan oleh masyarakat secara berkelanjutan. Agar masyarakat bersemangat dalam melanjutkan program ini, maka diajak untuk menangkap peluang pasar piring lidi. Pendampingan selanjutnya dilaksanakan oleh organisasi masyarakat desa Grogolpenatus, yaitu WG (Wong Grogol), yang selama ini sudah melakukan pendampingan terhadap masyarakat desa Grogolpenatus.

\section{Hasil dan Pembahasan}

Pemberdayaan merupakan suatu konsep yang lahir sebagai strategi dalam menjalankan pembangunan yang berbasis pada penggalian potensi sumber daya diri dan sekitarnya untuk bisa dimanfaatkan dalam rangka peningkatan taraf kehidupan masyarakat. Pemberdayaan sebisa mungkin dapat melakukan transformasi masyarakat dari yang tidak berdaya menjadi berdaya secara ekonomi sehingga menghasilkan nilai tambah bagi kemandirian ekonomi pedesaan, khususnya yang dapat menciptakan kekhasan desa (Herlina et al., 2018). Masyarakat diajak untuk menggali potensi yang ada di sekitarnya untuk kemudian memanfaatkan secara ekonomi.

Skala pemberdayaan yang dilakukan dalam program pengabdian ini adalah pada skala makro, dimana masyarakat yang memiliki karakteristik heterogen. Kelompok masyarakat yang terlibat pada program pemberdayaan masyarakat di desa Grogolpenatus ini, yaitu mulai dari ibu rumah tangga, pemuda desa yang tergabung dalam paguyuban pemuda semacam karang taruna. Kedua kelompok masyarakat tersebut dapat bekerjasama dengan baik saling mendukung untuk terlaksananya kegiatan pemberdayaan masyarakat dalam bentuk pelatihan anyaman lidi. Para pemuda semangat dalam melakukan perencanaan dengan dukungan mahasiswa KKN dari IAIN Purwokerto. Jauh sebelum itu, para pemuda diajak untuk menggali dan menemukan ptensisumber daya alamyangada di sekitar yang belum termanfaatkan dengan baik. Dari hasil brainstorming ditemukan limbah lidi yang belum termanfaatkan.

Ibu-ibu yang tergabung dalam kelompok PKK menyambut baik rencana yang diusulkan 
oleh para pemuda. Ibu-ibu banyak yang mendukung kegiatan pelatihan anyaman lidi ini karena ternyata selama ini sebenarnya potensi tersebut ada, namun mereka tidak menyadarinya. Dengan pelibatan dua unsur masyarakat dalam program pemberdayaan ini maka masuk kategori pemberdayaan dalam skala makro.

Sasaran pemberdayaan masyarakat yaitu mereka yang lemah atau tidak memiliki daya atau kekuatan dalam mengakses sumber daya produktif, atau masyarakat yang terpinggirkan dalam pembangunan (Widjajanti, 2011). Masih menurut Widjajanti, tujuan akhir pemberdayaan masyarakat yaitu dalam rangka memandirikan masyarakat agar bisa meningkatkan taraf hidup keluarga dan mengoptimalkan sumber daya yang dimilikinya.

Paradigma lama dalam pemberdayaan masyarakat adalah paradigma top-down, yaitu program yang datang dari pemerintah kemudian masyarakat hanya sebagai obyek obyek yang diperlakukan sesuai keinginan pemerintah. Namun saat ini paradigma tersebut telah beralih menjadi pemberdayaan dengan paradigma partisipatif (Wahyudin, 2012). Paradigma ini mengajak masyarakat sebagai subyek atau aktor yang aktif memikirkan dan melakukan pemberdayaan secara mandiri dengan dibantu oleh fasilitator.

Sulistiyani dalam (Miradj \& Sumarno, 2014) menjelaskan mengenai tahap-tahap pemberdayaan yaitu: 1) tahap pembentukan perilaku, yaitu tahap dimana masyarakat diajak untuk mengenali dan memahami potensi yang ada pada dirinya dan lingkungan disekitarnya. Dalam hal ini masyarakat desa Grogolpenatus diajak untuk menggali potensi ekonomis yang selama ini terabaikan. 2) tahap proses transformasi pengetahuan dan kecakapan keterampilan dapat berlangsung baik. Tahap ini bisa berjalan dengan baik jika pembentukan perilaku pada tahap pertama telah berhasil. Transformasi pengetahuan bisa dalam bentuk pemberian pelatihan keterampilan yang bermanfaat untuk masyarakat. 3) tahap pengayaan atau peningkatan intelektualitas dan kecakapan keterampilan agar terbentuk kemandirian, sehingga program bisa berkelanjutan.

\section{Potensi Ekonomi Lidi}

Pohon kelapa adalah salah satu pohon yangtumbuhsuburdi dataran tropis. Indonesia yang beriklim tropis menjadi tempat yang banyak ditumbuhi pohon kelapa. Masyarakat sangat familiar dengan pohon kelapa yang bisa dimanfaatkan seluruh bagiannya. Batang pohon kelapa dimanfaatkan untuk bahan bangunan, sedangkan buah kelapa bisa dimanfaatkan untuk berbagai keperluan (Winarno, 2014). Selain buahnya, kulit kelapa juga dimanfaatkan untuk membuat kerajinan. Potensi kelapa yang bisa dimanfaatkan misalnya batok kelapa, sabut kelapa, dan lainlain.

Salah satu bagian pohon kelapa yang belum banyak dimanfaatkan adalah lidi. lidi merupakan batang daun kelapa yang memiliki kekuatan, namun juga lentur. Kelenturan ini menjadi kelebihan yang bisa dibentuk dengan mudah. Pemanfaatan paling populer lidi pada zaman dulu adalah untuk membuat biting untuk mengunci kemasan dari daun pisang. Dalam perkembangannya cukup banyak masyarakat yang memanfaatkan lidi untuk membuat kerajinan dalam berbagai bentuk.

Lidi bisa didapatkan dengan mudah oleh warga desa Grogolpenatus. Lidi di desa Grorolpenatus belum dimanfaatkan secara 
optimal, padahal potensitersebutsangatbesar. Jika masyarakat dapat memanfaatkannya dengan baik akan bisa mendatangkan keuntungan ekonomi masyarakat.

Lidi sebenarnya bukan limbah, karena masih bisa diolah menjadi komoditas mendatangkan penghasilan tambahan. Pemanfaatan yang paling banyak adalah sebagai sapu lidi. potensi manfaat lain adalah denganmenjadikannyabahanbakupembuatan piring ramah lingkungan. Masyarakat semakin banyak yang menggunakan piring lidi. hal ini disebabkan oleh beberapa keunggulan piring lidi dibanding dengan piring konvensional. Beberapa keunggulan tersebut diantaranya: 1) praktis, tidak perlu mencuci setiap kali selesai dipakai, sehingga bisa menghemat air dan deterjen. 2) tidak khawatir pecah seperti piring yang terbuat dari bahan non organik yang juga dapat membahayakan keselamatan penggunanya. 3) ikut melestarikan ekosistem alam karena mengurangi penggunaan barang berbahan kimia.4) harga relatiflebih murah.5) berpartisipasi dalam menggerakkan ekonomi desa, dengan membeli produk piring lidi. Dalam memanfaatkan lidi tersebut, pemateri mendemonstrasikan cara menganyam lidi kepada para peserta sebagaimana pada gambar 1 dan 2:

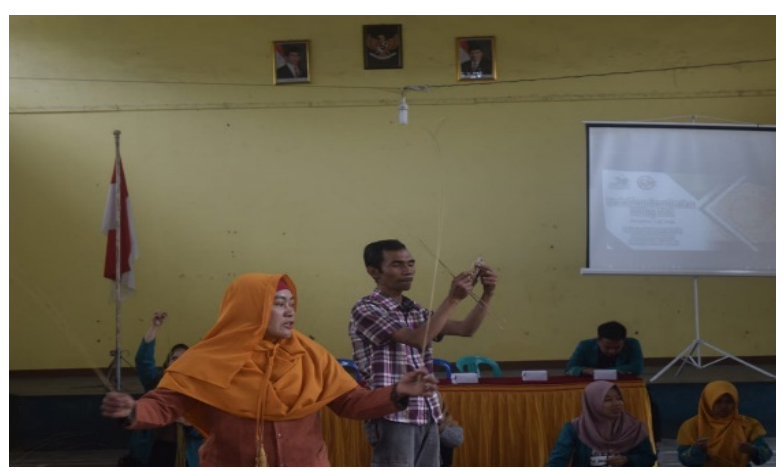

Gambar 1. Pemateri mendemonstrasikan cara menganyam lidi kepada para peserta.

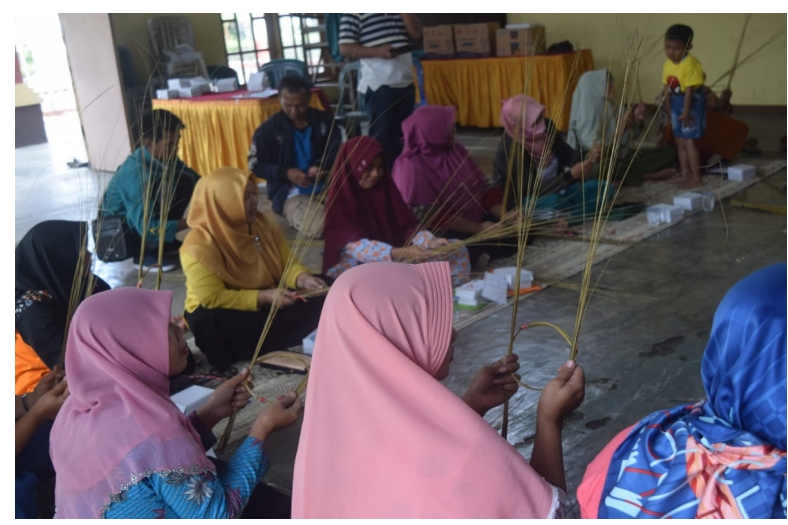

Gambar 2 peserta mengikuti arahan pemateri Latihan menganyam lidi

Desa Grogolpenatus merupakan salah satu desa yang terletak di kecamatan Petanahan kabupaten Kebumen. Desa ini berada dekat dengan salah satu obyek wisata pantai Petanahan yang menjadi salah satu wisata populer di kabupaten Kebumen. Selain itu, desa ini juga berdekatan dengan pusat pemerintahan kecamatan Petanahan, sehingga bisa dikatakan tidak terlalu tertinggal. Salah satu komoditas yang dihasilkan oleh desa ini yaitu buah kelapa. Di pekarangan warga yang masih luas, banyak ditanami pohon kelapa yang tinggi dan umurnya sudah cukup tua. Kelapa adalah salah satu komoditas pertanian yang buahnya tidak mengenal musim. Buah kelapa bisa dipanen setiap saat tanpa mengenal jeda.

Pemanfaatan pohon kelapa baru sebatas pada buah dan batangnya saja. Kalaupun memanfaatkan daunnya, sebatas hanya sebagai pemantik api tungku untuk memasak di dapur. Di saat semakin marak penggunaan gas elpiji sebagai alternatif memasak, maka daun kelapa semakin banyak menumpuk dan tidak dimanfaatkan. Padahal di sisi lain, masyarakat banyak yang hanya mengandalkan pertanian sawah musiman. Di desa Grorolpenatus memiliki komunitas pemuda yang peduli terhadap 
kondisi desa, memiliki kemauan untuk ikut berkontribusi terhadap rembug warga desa dalam mencari berbagai peluang yang bisa dimanfaatkan meningkatkan taraf ekonomi warga. Ketika kedatangan mahasiswa KKN dari IAIN Purwokerto, perkumpulan pemuda ini menyambut dengan sangat antusias. Sambutan yang antusias ini menjadikan mahasiswa semakin semangat dalam melaksanakan KKN di desa tersebut. Bersama perkumpulan pemuda desa Grogolpenatus, mahasiswa KKN dan DPL KKN melakukan diskusi mengenai berbagai program kerja yang kiranya bisa dilaksanakan dan sesuai dengan kebutuhan warga desa Grogolpenatus. Dengan semangat dan modal seadanya dan didukung oleh perkumpulan pemuda dan segenap warga desa, maka disepakati untuk membuat kegiatan pelatihan anyaman lidi.

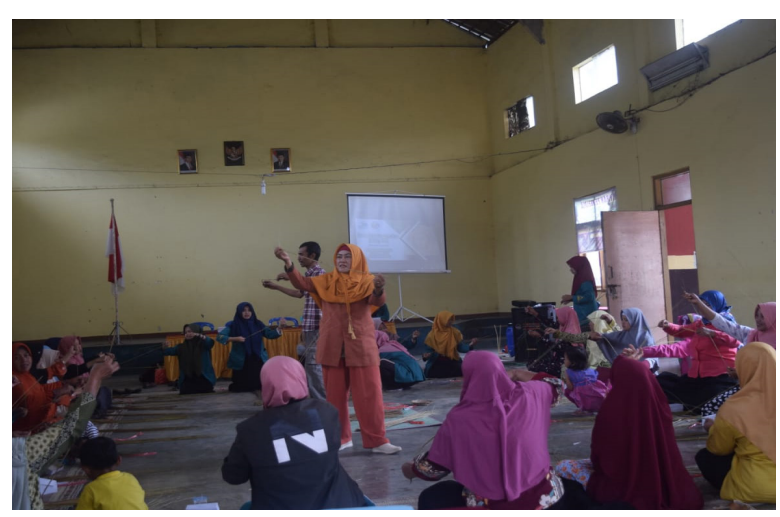

Gambar 3. Peserta antusian mengikuti pelatihan anyaman lidi di kantor desa Grogolpenatus, Petanahan, Kebumen.

Pelatihan anyaman lidi dengan mendatangkan pemateri Tugi Yoda dan kemudian menyampaikan materi dari proses penyiapan bahan baku hingga penganyaman dan peluang pemasaran. Dengan pelatihan yang telah dilaksanakan tersebut, diharapkan bisa menjadi alternatif bagi warga untuk mendapatkan penghasilan tambahan dengan memanfaatkan bahan yang tersedia di sekitarnya. Harapan yang lebih jauh lagi tentunya dapat menjadi penopang ekonomi keluarga dan meningkatkan taraf hidup keluarga. Harapan jangka panjang, jika memang warga terus menekuni kegiatan anyaman lidi bisa menjadi salah satu ikon baru desa Grogolpenatus.

Setelah dilaksanakan pelatihan tersebut, ibu-ibu PKK menjadi paham dan mampu mempraktikkan proses anyaman lidi mulai proses penyiapan bahan baku hingga pengemasan dan siap jual. Warga selanjutnya bisa mempraktikkan di rumah masingmasing keterampilan yang telah didapatkan saat pelatihan. Walaupun belum sampai pada taraf produksi massal, hasil anyaman bisa mulai dijual di pasar Petanahan dan obyek wisata pantai Petanahan yang tidak jauh dari desa Grogolpenatus.

\section{Kesimpulan}

Secara umum kegiatan pengabdian kepada masyarakat desa Grogolpenatus berjalan dengan lancar sesuai rencana. Namun ada beberapa catatan terkait kegiatan tersebut. Pertama, karena terbatasnya dana yang disediakan maka peserta yang ikut pelatihan juga terbatas. Hal ini cukup disayangkan karena sebenarnya banyak warga lain yang ingin ikut pelatihan tersebut. Kedua, ibu-ibu PKK perlu menularkan lebih luas lagi ilmunya kepada warga, terutama ibu-ibu rumah tangga di wilayah Grogolpenatus. Ilmu jika tidak diamalkan dan ditularkan kepada orang lain maka kana cepat menghilang. Namun semua kembali kepada ibu-ibu PKK, semoga punya semangat untuk menularkan pengetahuan dan keterampilannya kepada warga. Harapannya desa Grogolpenatus suatu saat bisa menjadi sentra kerajinan anyaman lidi dan menjadi salah satu ikon baru desa Grogolpenatus. 


\section{Referensi}

Azzahra, F., \& Hasan, Y. (2018). Meningkatkan Keterampilan Membuat Piring Anyaman Lidi melalui Strategi Joyful Learning bagi Anak Tunagrahita Ringan. Jurnal Penelitian Pendidikan Kebutuhan Khusus, 6(2006), 200-205.

Budiningsih, W. (2019). Strategi Pemberdayaan Masyarakat melalui Dana Desa sebagai Upaya Pengentasan Kemiskinan (Studi Kasus pada Desa Melung Kecamatan Kedungban-teng, Kabupaten Banyumas) (Doctoral dissertation, IAIN Purwokerto).

Deti, S. (2017). Pemberdayaan Ekonomi Umat melalui Pembiayaan Mikro Syariah. elJizya: Jurnal Ekonomi Is-lam, 5(1), 141176.

F., F., Maricar, S., \& Asnudin, A. (2018). Pemanfaatan Lidi Daun Kelapa da-lam Meningkatkan Penghasilan Ibu-ibu Buruh Tani Kelapa. SNP2M, 2018, 46-50. Ujung Pan-dang: Politeknik Negeri Ujung Pandang.

Haris, A. (2014). Memahami Pendekatan Pemberdayaan Masyarakat. Jupi-ter, 13(2).

Hatu, R. (2010). Pemberdayaan dan Pendampingan Sosial dalam Masyarakat (Suatu Kajian Teor-tis). Jurnal inovasi, $7(04)$.

Herlina, E., Yuliani, D., Kader, M. A., \& Syarifudin, D. (2018). Peningkatan Produktifitas Kerajinan Lidi Berbasis Pendampingan Desain dan Pemasaran Online. Jurnal Pengabdian Kepada Masyarakat, 8(2). https://doi. org/10.30999/jpkm.v8i2.269.

Indarti, L. P. (2019). Peranan Bank Sam- pah dalam Pemberdayaan Ekonomi Masyarakat (Studi Kasus pada Bank Sampah Adipati Mersi Keca-matan Purwokerto Timur Kabu-paten Banyumas) (Doctoral disser-tation, IAIN Purwokerto).

Irianti, M., Syahza, A., Asmit, B., Bakce, D., \& Tampubulon, D. (2018). Peningkatan Pendapatan Masyarakat Me-lalui Pemanfaatan Limbah Lidi Ke-lapa Sawit di Desa Sepahat Kabu-paten Bengkalis. Prosiding Seminar Hasil Pengabdian Kepada Masyara-kat, 9. Jakarta: UPN Veteran Jakar-ta.

Kurniawati, D. P. (2013). Pemberdayaan Masyarakat di Bidang Usaha Ekonomi (Studi pada Badan Pem-berdayaan Masyarakat kota Mo-jokerto). Jurnal Administrasi Pub-lik, 1(4), 9-14.

Laksono, W. U. (2016). Manajemen Bank Sampah dalam Pemberdayaan Ekonomi Nasabah (Studi Kasus pada Bank Sampah PAS (Peduli Akan Sampah) Arcawinangun, Purwok-erto, Banyumas) (Doctoral disser-tation, IAIN Purwokerto).

Magga, R., \& Jamaluddin. (2019). Pemberdayaan Masyarakat melalui Kelompok Home Industry Anyaman Lidi yang Berbasis Kearipan Lokal sebagai Penyangga Utama Ekonomi Rumah Tangga di Keca-matan Sindue. Jurnal Inovatif Pengabdian Masyarakat, 2(1), 12-15.

Martiarini, R. (2017). Strategi Pengem-bangan Desa Wisata Melalui Pem-berdayaan Masyarakat Desa Ke-tenger Baturraden (Doctoral dis-sertation, IAIN).

Miradj, S., \& Sumarno. (2014). The Empowerment of The Poor Through The 
Non-Formal Education.Jurnal Pendidikan Dan Pemberdayaan Masyarakat, 1(2), 101-112.

Nasdian, F. T. (2014). Pengembangan masyarakat. Yayasan Pustaka Obor Indonesia.

Putra, C. K. (2013). Pengelolaan Alokasi Dana Desa dalam Pemberdayaan Masyarakat Desa (Studi Pada Desa Wonorejo Kecamatan Singosari Kabupaten Malang). Jurnal Admin-istrasi Publik, 1(6), 1203-1212.

Rahman, A., \& Budiywono, E. (2018). Pemanfaatan Lidi Daun Kelapa Menjadi Handycraft dalam Bentuk Anyaman Piring Lidi di Desa Pur-woasri Kecamatan Tegaldlimo Ka-bupaten Banyuwangi. Loyalitas: Jurnal Pengabdian Kepada Masyarakat, 1(1), 11-20.

Setiawan, A. I. (2012). Dakwah Berbasis Pemberdayaan Ekonomi dan Peningkatan Kesejahteraan Mad'u. Ilmu Dakwah: Academic Journal for Homiletic Studies, 6(2), 347-262.

Silmi, A. F. (2017). Participatory Learn-ing And Action (PLA) di Desa Ter-pencil: Peran LSM Provisi Yogya-karta dalam Pemberdayaan Masyarakat di Lubuk Bintialo Su-matra Selatan. Jurnal Pemberdayaan Masyarakat: Media Pemikiran dan Dakwah Pem-bangunan, 1(1), 83102.

Siregar, I. (2007). Proses Pembuatan Komposit Hibrida Lidi Kelapa Se-bagai Bahan Bangunan Alternatif. Universitas Islam Indonesia.

Soleh, A. (2017). Strategi Pengem-bangan Potensi Desa. Jurnal Sungkai, 5(1), 3252.
Suryawan, A. (2016). Peran Kelompok Sadar Wisata (Pokdarwis) Sen-dang Arum dalam Pengembangan Potensi Pariwisata (Studi Kasus di Desa Wisata Tlahap Kecamatan Kledung Kabupaten Temanggung). Jurnal Elektronik Mahasiswa Pend. Luar Sekolah-S1, 5(6), 143-152.

Utama, S. (2010). Pemberdayaan Masyarakat Sekitar Hutan melalui Pendekatan Kelompok: Kasus Pengelolaan Hutan Bersama Masyarakat pada Areal Hutan Produksi Perum Perhutani Unit I Provinsi Jawa Tengah.

Wahyudin, U. (2012). Pelatihan Kewirausahaan Berlatar Ekokul-tural untuk Pemberdayaan Masyarakat Miskin Pedesaan. MIMBAR, Jurnal Sosial Dan Pem-bangunan, 28(1), 55. https:// doi.org/10.29313/mimbar.v28i1.339

Widjajanti, K. (2011). Model Pemberdayaan Masyarakat. Jurnal Ekonomi Pembangunan, 12(1).

Winarno, F. G. (2014). Kelapa Pohon Kehidupan. Jakarta: Gramedia.

Wuysang, R. (2014). Modal Sosial Kelompok Tani dalam Meningkatkan Pendapatan Keluarga Suatu Studi Dalam Pengembangan Usaha Ke-lompok Tani di Desa Tincep Kecamatan Sonder. Jurnal Acta Di-urna, 3(3).

Zuliyah, S. (2010). Strategi Pem-berdayaan Masyarakat Desa da-lam Menunjang Pembangunan Daerah. Journal of Rural and De-velopment, 1(2). 